\title{
$\checkmark$ Research Square \\ Production of Transgenic Allium Cepa By Nanoparticles To Resist Aspergillus Niger Infection
}

\section{Eman Tawfik Hussien ( $\nabla$ e_tifa@yahoo.com )}

Helwan University Faculty of Science https://orcid.org/0000-0001-5574-7476

Ibtisam Abd El-Ghany Hammad

Helwan University Faculty of Science

Ashraf Bakry Abdel Razik

Ain Shams University Faculty of Agriculture

\section{Research Article}

Keywords: Allium cepa, Aspergillus niger, Chitosan nanoparticles, Thionin, Transformation

Posted Date: September 2nd, 2021

DOl: https://doi.org/10.21203/rs.3.rs-844813/v1

License: (1) This work is licensed under a Creative Commons Attribution 4.0 International License.

Read Full License 


\section{Abstract}

Transgenic plants are becoming a more powerful tool in modern biotechnology. Genetic engineering was used in biotech-derived products to create genetically modified (GM) plants. Plant bioreactor systems have proven to be extremely effective in the production of disease resistance plants. The onion (Allium cepa, L.) is a common, important perennial vegetable crop grown in Egypt for food and economic value. Onions are susceptible to a variety of fungal infections and diseases. Aspergillus niger is a common onion phytopathogen that causes diseases such as black mould (or black rot), which is a major issue, particularly when exporting onions. A.nigergrows between the bulb's outer (dead, flaky) skin and the first fleshy scales, which become water-soaked. Thionin genes produce thionin proteins, which have antimicrobial properties against a variety of phytopathogens, including $A$. niger. Chitosan nanoparticles act as a carrier for the thionin gene, which allows $A$. cepa to resist infection by $A$. niger. Transgenic $A$. cepa has a high level of resistance to fungal infection. Transgenic $A$. cepa had a $27 \%$ weight inhibition compared to non-transgenic one, which had a $69 \%$ inhibition. The expressed thionin protein has a $52 \%$ inhibitory effect on $A$. niger spore germination. All of these findings supported thionin protein's antifungal activity as an antimicrobial peptide. Furthermore, the data presented here demonstrated the efficacy of chitosan nanoparticles in gene transformation. The present study describes the benefits of producing transgenic onion resistance to black rot diseases.

\section{Introduction}

The onion (Allium cepa, L.) belongs to the Alliaceae family and is indigenous to the Middle East and Asia. It's a seasonal crop, a bulbous biennial herb with bulbs that grow underground. Essential minerals, vitamins, carbohydrates, and amino acids in $A$. cepa give it food and medical properties. Because of its high content of fructans, flavonoids, macro- and micronutrients, the onion is used as a potherb and contains an essential component of the human food chain. The onion plays an important role in folk medicine because it helps to prevent heart disease and other illnesses $[1,2]$.

Onions can be infected by several post-harvest diseases such as black mold rot caused by Aspergillus niger. The most destructive disease of storage in the field is onion black mould rot, which is a major problem when exporting. The pathogen is spread by infected seeds or soil. The infection usually starts with the germination of onion seeds and can last for months. Visual external and internal symptoms of black mold are noticed on bulbs. However, these symptoms are not visualized on seeds. A. niger produced several enzymes and toxins in the bulb and other tissues $[3,4]$.

To defend themselves against pathogens, plants produce a variety of antimicrobial peptides, including thionins. Thionins are known to have antimicrobial properties and are a part of the plant defence system. Thionins are short peptides of about 5 kDA with antimicrobial activity. They are expressed in many monocotyledons and dicotyledon plants, as about one hundred thionin sequences have been described in fifteen plant species. Regarding pathogen attack, the expression of thionin genes is regulated by methyl jasmonate hormone which has an essential role in defense reactions $[5,6,7,8,9,10]$. Asano et al. [11] 
explained the mechanism of thionins inhibition of pathogenic fungi: thionins' antimicrobial properties comes from their ability to cause pore formation on phytopathogen cell membranes, allowing potassium and calcium ions to escape the cell.

The transformation of gene of interest identified is by different methods which were classified into two types (indirect and direct). The indirect method involves the use of a vector to deliver gene. The direct method is directly by various chemical and physical ways of gene transfer. The genetic diversity exists in available species are analyzed to identify the gene of interest to develop an elite cultivar [12]. Chitosan nanoparticles provide an efficient and rapid direct method for gene transformation. Biodegradable polymers like chitosan can detect an advantageous charge on the DNA conjugate nanomaterial surface. Chitosan is a polymer that has been widely used in nucleic acid delivery and tissue engineering packages $[13,14]$.

Gene delivery using chitosan-based polysaccharides have gained significant attention in recent years as new functional biomaterials with potential applications in various fields. Chitosan chemical properties are insoluble in most solvents but slightly soluble in diluted organic acids such as acetic, lactic, malic, formic, and succinic acids. The degree of deacetylation (DDA) of a chitosan biomaterial is the actual molarity of the glucosamine residue in the polymer chain to indicate the cationic charge on the molecule once diluted in acid solution. This is clearly evident from the proportion of free amino groups in the chitosan biopolymer $[15,16]$. Chitosan-derived biomaterials have received considerable attention as an antimicrobial, functional, renewable, nontoxic, biocompatible, bioabsorbable, and biodegradable biopolymer agent $[17,18,19]$.

The study aims to design new transgenic onion lines resistant to a fungal infection caused by Aspergillus niger. Thionin (Thio-60) is the target gene with antimicrobial activity expressed into antimicrobial thionin peptides. This gene was transformed via chitosan nanoparticles.

\section{Materials And Methods}

\section{Plant material}

The thionin gene is genetically modelled in the Arabidopsis thaliana plant according to previous study of Abdel-Razik et al. [19]. Onion cultivar was used as a transgenic model (Giza red). They were purchased from Agricultural Research Center and regenerated on MS media [20].

\section{Obtainig of thionin gene and Cloning}

Edward's protocol was used to extract total genomic DNA from Arabidopsis thaliana [21]. For each $25 \mu \mathrm{l}$ PCR reaction, 50ng of template DNA was used. Also, contained $12.5 \mu \mathrm{l}$ of $2 \mathrm{X}$ master mix (Biolene), $1 \mu \mathrm{l}$ of each forward and reverse primer (50nmole/base), and sterile d. $\mathrm{dH}_{2} \mathrm{O}$ to fill the remaining $25 \mu \mathrm{l}$. The primers were designed with the snap gene ${ }^{\circledR}$ (2.3.3) and had the following sequences: Thio-60F: $5^{\prime}$ GCTGAATTCATGgAgGACAAAAGA 3', Thio-60R: 5' GCTAAGCTTTCATAGACTAAAATCAAT 3'. The PCR 
reaction was run for 40 cycles: 1 minute at $95^{\circ} \mathrm{C}, 1$ minute at $64^{\circ} \mathrm{C}$, and 1 minute at $72^{\circ} \mathrm{C}$. On a $1.2 \%(\mathrm{w} / \mathrm{v})$ agarose gel, thionin insert were run. GeneJETTM PCR Purification Kit was used to purify the amplified PCR product (Thermo K0701). pMiniT Vector (NEB® PCR Cloning Kit, \#E1202S - 10-beta Competent $E$. coli) was ligated to the Thio-60 product. Following the manual's instructions.

\section{Confirmation of Bacterial Transformation}

Colony PCR was used to differentiate non-recombinant and recombinant colonies, and colony PCR was used to apply colony PCR. On LB agar plates supplemented with $100 \mu \mathrm{g} / \mathrm{L}$ ampicillin, bacteria containing modified plasmid were grown. Single colonies were used as templates for PCR reactions using the same thionin primers, followed by electrophoresis on a 1.2 percent gel.

\section{Chitosan nanoparticle transformation}

\section{Degree of Deacetylation}

Titration method was used to determine the degree of deacetylation for chitosan nanoparticles according to Czechowska-Biskup et al. [22] as follow: "Dried chitosan $(0.2 \mathrm{~g})$ was dissolved in $20 \mathrm{ml}$ of $0.1 \mathrm{M}$ hydrochloric acid and $25 \mathrm{~cm}^{3}$. After 30 min continuous stirring $25 \mathrm{ml}$ of $\mathrm{dH}_{2} \mathrm{O}$ was added with continuous stirring for another 30 minutes. After complete dissolve of chitosan, titration with a $0.1 \mathrm{~mol} \cdot \mathrm{dm}^{-3}$ sodium hydroxide solution was performed. The degree of deacetylation (DA or DD) of chitosan was calculated as:

$D A \%=2.03\left(\frac{V 2-V 1}{m+0.0042(V 2-V 1)}\right)$

Where: $\mathrm{m}$ : weight of sample, V1, V2: consumed volumes of $0.1 \mathrm{~mol} \cdot \mathrm{dm}-3$ sodium hydroxide solution, 2.03: coefficient of the molecular weight of chitin monomer unit, 0.0042: coefficient of the difference between molecular weights of chitin and chitosan monomer units".

\section{UV-Visible Spectra Measurements and Zeta Potential and Size}

Another characterization method for chitosan nanoparticles is using UV-visible spectroscopy "JASCO V630 UV-visible spectrophotometer (serial: C285061148) with Spectra Measurement software”. The measured zeta potential and size was estimated using Malvern (7.2) software.

\section{Transmission electron microscopy}

The examined CS nanoparticles were prepared as follow: "copper grids mesh coated with carbon 400 and handled on 1 drop of the prepared complex (CS/pDNA) and left for $1.5 \mathrm{~min}$. The grid was stained with 1 drop of filtered solution of $2 \%$ uranyl acetate for $1.5 \mathrm{~min}$, with removal of excess uranyl acetate [23]. The grids were dried for 10 min then photographed with transmission electron microscope (TEM) in the Regional Center for Mycology and Biotechnology, Al-Azhar University". 


\section{Preparation of chitosan-DNA nanoparticles complex (CS/pDNA)}

Mansouri et al. [24] designed the protocol of CS/DNA formation as follow: "chitosan nanoparticles (CS) were dissolved in $25 \mathrm{mM}$ acetic acid and adjusted to $\mathrm{pH} 5.5$ at a concentration of $0.08 \%$. Both CS and recombinant pMiniT were incubated in water bath at $55^{\circ} \mathrm{C}$ for $15 \mathrm{~min}$ and then added equally to each other with stirring on a vortex for $1 \mathrm{~min}$.

\section{Transformation of Chitosan/pDNA into Allium cepa}

The method of chitosan nanoparticle transformation into plant tissue was developed by [19]: "Seedlings of $A$. cepa were inoculated by syringe containing CS/pDNA complex. After that the explants were transferred on to MS medium supplemented with $(2 \mathrm{mg} / \mathrm{L} \mathrm{BA}$ and $1 \mathrm{mg} / \mathrm{l} \mathrm{kin})$ hormones and $100 \mu \mathrm{g} / \mathrm{L}$ ampicillin then incubated at $25 \pm 1^{\circ} \mathrm{C}$ for 4 weeks to regenerate plants".

\section{Molecular analysis of Transgenic Allium cepa Lines}

DNA from both leaves of non-transgenic and transgenic Allium cepa lines was isolated. DNA fragments of thio- 60 transgenes were amplified by PCR with the same thionin primers and the same PCR program conditions.

\section{Pathogenicity bioassay}

A fungal-resistance assay of transgenic plants was used to accomplish this. The thionin genes in transgenic plants were tested for antimicrobial activity against $A$. niger. Pathogenicity bioassay was performed via three methods: 1) Spore suspension infecting whole Allium cepa shoot; 2) infection of whole in vitro plant and 2) spore suspension infecting plants out-jars (after 2 weeks of growth).

\section{Spore suspension infecting whole Allium cepa shoot}

In another experiment, spore suspension was prepared by immersing fungal discs in $5 \mathrm{ml}$ of sterile distilled water to release the spores. The spores were collected with a sterile Pasteur pipette, and their concentration was adjusted to $2 \times 105$ spores $/ \mathrm{ml}$ using sterile water. This assay was applied for the whole shoot with some modifications.

The whole shoot from mature transgenic and non-transgenic $A$. cepa, grown in vitro for 4 weeks, were placed in a Petri dish with wet filter paper and inoculated with the spore suspension (100 $\mu$ leach). After inoculation, the shoots were incubated at room temperature under $16 \mathrm{~h}$ light/ $8 \mathrm{~h}$ dark conditions and high humidity for a week. Pictures were taken 5 days after inoculation [25].

\section{Disease Resistance Assay}

For fungal infection: this follows [25] and [26] with some modification. "Fungi grew on potato dextrose agar till the surface covered with the fungal mycelia. Then, a block of the agar with mycelia was placed near to the base of in vitro transgenic and non-transgenic control plants ( 3 weeks old) grown on 100ml 
MS medium and incubated at $25^{\circ} \mathrm{C}$ with $16 \mathrm{~h}$ light $/ 8 \mathrm{~h}$ dark. Photographing for the results was recorded 2 weeks after inoculation".

\section{Spore Suspension with Infected plant}

The spore suspension of $A$. niger was prepared by submerging fungal discs in $5 \mathrm{ml}$ of sterile $\mathrm{dH}_{2} \mathrm{O}$ to release the spores (adjust concentration to $2 \times 10^{5} \mathrm{spores} / \mathrm{ml}$ using sterile $\mathrm{dH}_{2} \mathrm{O}$ ). This assay was applied for whole of plants from mature transgenic and non-transformed $A$. cepa, grown in vitro for 4 weeks, put in a Petri plate with wet filter paper, and inoculated with the spore suspension (100 $\mu$ l each). After inoculation, these infected leaves were incubated at room temperature and high humidity for 7 days then photographed to record the infection symptoms [25].

\section{Inhibitory Protein Bioassay}

The antifungal activity of the transgenic Allium's product thionin proteins was tested against $A$. niger spores. Bradford's method [27] of protein extraction was used to extract the proteins. Then, with some modifications, the inhibitory effect of protein extracts on spore germination bioassay was used, as described by Maji et al. 2005. "The pathogens' spore suspension was made aseptically from a 7-day-old pure culture. On separate sterile eppendorf tubes, $100 \mu \mathrm{l}$ of spore suspension and $100 \mu \mathrm{l}$ of crude protein extracts were taken. One tube was kept as a control, with no extract added. Triplicates of each treatment were kept. The tubes were incubated at $25 \pm 2^{\circ} \mathrm{C}$ for $24 \mathrm{~h}$. After the incubation period, observations were made under microscope to calculate the percentage inhibition" (using 100x magnification power under JENLAB microscope).

\section{Statistical analysis}

The data in this study were analyzed using one-way anova in SPSS 21 software for calculating means and the significance for 10 individuals for each sample. The data analysis of gel was performed using BioRAD Quantity One software (4.6.2).

\section{Results And Discussion}

The thio-60 gene was transformed into Allium cepa using chitosan nanoparticles. The transgenic plants exhibited resistance against Asperigillus niger infection.

Thio-60 was isolated from Arabidopsis thaliana and then obtained via PCR using specific primers. Following that, the PCR product of each gene was ligated into the pMini-T vector separately. The recombinant plasmids were then transformed into competent 10-beta (Fig. 1). A colony PCR was used to confirm thionin transformation into 10-beta for amplification. Thio-60 was found at approximately 640 bp.

Many antifungal genes were isolated from several plants, like Liu et al. [28] who isolated Pa-AMP-1 from Phytolacca americana. Also, Plattner et al. [29] isolated the antimicrobial BTH6 thionin from barley. 
Almaghrabi et al. [30] isolated a category of thionins from Arabidopsis and proved anti-nematodes.

\section{Chitosan nanoparticle characterization}

DD, morphology TEM measurements, UV-Visible spectroscopy, and zeta potential were used to characterise chitosan nanoparticles (Table 1). TEM images (Fig. 2) separately depicted the complex of chitosan nanoparticles with modified plasmids carrying thionin genes. The absorbance of chitosan nanoparticles was determined to be $302.8 \mathrm{~nm}$ using UV-visible measurements (Fig. 3). The distribution of zeta potential of these chitosan nanoparticles was 28 (Fig. 4).

Chitosan nanoparticle is a modern technique used for transformation because it has many advantages: nontoxic, biocompatible, and biodegradable compared with the Agrobacterium technique. The CS/pDNA complex was effeciently prepared and applied as an effective gene delivery system under controlled conditions. This agreed with Hussein [31], who applied chitosan nanoparticles as a carrier of pMiniT carrying thionin gene via transformation to Paulownia sp. Czechowska-Biskup et al. [22] used a simple titration method to determine the degree of deacetylation (DD), which evaluates the amine or acetyl amine groups on the glycoside unit of chitosan nanoparticle. The affinity between the nanoparticle and pDNA is determined by the positive charge of this group joining with the negative charge of pDNA. In addition, the degree of deacetylation determines the content of free amino groups in the polysaccharide, which have an essential role in binding between chitosan and DNA.

In our work, we used the ratio 1:1 (pDNA: CS) and confirm that DNA union with chitosan depend on both molecular weight and the DD of chitosan nanoparticles and these results were the same manner with Kiang et al. [23] who indicated that the ratio between the DNA and chitosan concentration must be the same ratio. Also, in agreement with Bivas-Benita et al. [32], who demonstrated that particle size and shape play an important role in gene transfer into cells.

According to Kiang et al. [23], who photographed chitosan nanoparticles in colon cancer cells using a plasmid carrying the HEK293 gene (human embryonic kidney cells); and Hallaj-Nezhadietel et al. [33], who photographed the pUMVC3-hIL12 complex on chitosan nanoparticles in colon cancer cells using a plasmid carrying the HEK293 gene (human embryonic kidney cells. Till now, only a few research have focused on the use of chitosan in plants, and the work in this field has been too limited, according to [19], who photographed chitosan nanoparticle binding with the pEGAD, and Hussien [31] who described chitosan nanoparticle using SEM.

Table 1

Description and characterization of chitosan nanoparticles

\begin{tabular}{|llllll|}
\hline Character & Morphology & pH & $\begin{array}{l}\text { Zeta } \\
\text { Potential }\end{array}$ & $\begin{array}{l}\text { Particle size } \\
\text { "nm." }\end{array}$ & $\begin{array}{l}\text { Average } \\
\text { DD }\end{array}$ \\
\hline $\begin{array}{l}\text { Chitosan } \\
\text { description }\end{array}$ & $\begin{array}{l}\text { Powder, Whitish- } \\
\text { yellow }\end{array}$ & 4.4 & 28 & 173.3 & $\begin{array}{l}51.23 \pm \\
5.765\end{array}$ \\
\hline
\end{tabular}

Transformation of Chitosan/pDNA into Allium cepa 
After four weeks of incubation at $25^{\circ} \mathrm{C}$, the regenerated transgenic and non-transgenic lines of $A$. cepa were fully grown (Fig. 5). Chitosan nanoparticles were used for the transformation of various genes in different sources like animal and human cell lines, according to Kiang et al. [23] and Hallaj-Nezhadietel et al. [33]. However, till limited application in gene transformation into plant tissues, until [19] used chitosan nanoparticles for gene transformation to potato lines.

Confirmation of thionin gene transformation into A. cepa was applied using PCR for both transgenic and non-transgenic lines. The band was detected at $640 \mathrm{bp}$ for thio-60. The non-transgenic lines were applied to confirm that the thionin gene was not found previously in this species.

\section{Pathogenicity test}

The spore suspension bioassay, Aspergillus niger was applied to infect the entire plant out-jars. Fungal discs were used to infect the whole plant jar, and spore suspension was applied to infect $A$. cepa transgenic lines comparing to non-transgenic one. The inhibition percentage in the growth after and before infection was calculated and recorded in table (2). The percentage in growth in non-transgenic lines $(69.746 \%)$ was higher than transgenic ones $(27.393 \%)$, and this is a high significant difference (Fig. 6b).

In the inhibitory protein bioassay, the expressed total proteins were used to inhibit spores' germination. The results obtained from infected onion jars were precise and made a difference between transgenic and non-transgenic lines (Fig. 6a), where the bioassay of spore suspension infecting shoot was shown in (Fig. 6b). The reverse effect of transgenic thionin protein on spore germination was explained in Fig. (7) and table (3). The in vitro culture of transgenic A. cepa showed significant growth and resistance to fungal infection comparing to non-transgenic one, which showed high inhibition in growth. The results showed a highly significant difference of transgenic Allium expressing thio-60 comparing to nontransgenic Allium. The inhibition percentage in weight of non-transgenic Allium was $36 \%$, wherein the transgenic one with thio-60 was $13 \%$.

This is agreed with Khan et al. [25], who produce transgenic potato cultivars (three commercial potato cultivars) resistant to Alternaria solani fungus to a high extent. It also agreed with Khan et al. [26], who partially produce a free disease-resistant potato cultivar to resist Alternaria solani, Botrytis cinerea, and Fusarium oxysporum.

The activity of protein extracts against the spore germination of phytopathogenic $A$. niger (Table 2 and Fig. 7) showed inhibition in spores germination treated with transgenic thionin protein. It was noticed that spores treated with $\mathrm{H}_{2} \mathrm{O}$ (as negative control) cause aggregation in spores, but still high number in growth and number of spores. In the case of spores treated with non-transgenic Allium protein, the number and germination of protein are less than negative control but still high. In the case of spores treated with protein extracted from transgenic Allium, expressing thionin protein, the spore germination was significantly inhibited. 
Cammue et al. [34] found that thionin proteins inhibit about 20 phyto-pathogens, including Botrytis cinerea, Fusarium spp., Phytophthora infestans, and Rhizoctonia solani. Epple et al. [35] found that constitutive overexpression of an endogenous thionin in transgenic Arabidopsis increased resistance to Fusarium oxysporum f. sp. matthiolae, implying that thionins are defence proteins. Asano et al. [11] used the secreted antifungal thionin protein isolated $A$. thaliana to suppress the toxicity of Fusarium graminearum, with results ranging from 20 to $50 \%$ inhibition using the spore suspension method.

Table 2

The average of inhibition percentage for the whole shoot of transgenic Allium cepa cultivars measurements in comparing to non-transgenic against Aspergillus niger infection

Inhibition \% of non-transgenic Allium cepa Inhibition \% of transgenic Allium cepa

$69.746 \pm 12.667$

$27.393 \pm 9.667$

Table 3

Effect of protein extracts from transgenic and non-trasgenic Allium cepa on spore germination of Aspergillus niger

\begin{tabular}{|lcllll|}
\hline $\begin{array}{l}\text { Spores treated with }\left(\mathrm{H}_{2} \mathrm{O}\right) \\
\text { Negative control }\end{array}$ & \multicolumn{2}{l}{$\begin{array}{l}\text { Spores treated with (non-transgenic } \\
\text { protein) Positive control }\end{array}$} & \multicolumn{2}{l|}{$\begin{array}{l}\text { Spores treated with } \\
\text { Thio-60 protein }\end{array}$} \\
\hline S.G. & Inh. \% & S.G. & Inh. \% & S.G. & Inh. \% \\
\hline $191.2 \pm 26.5$ & 37.55 & $162.0 \pm 25.0$ & 37.09 & $40.00 \pm 6.18$ & 52.49 \\
\hline
\end{tabular}

\section{Conclusion}

This work introduced the transformation of thionin gene (thio-60) isolated from Arabidopsis thaliana. This gene was transformed into Allium cepa cultivar (Giza red) by chitosan nanoparticle transformation. The transgenic $A$. cepa tissues were regenerated by seed culture technique. Resistance of transgenic $A$. cepa cultivar lines were assessed against phytopathogenic fungi (Aspergillus niger). The successful transformation was confirmed by using conventional PCR. The whole plant culture was subjected to $A$. niger and showed resistance to fungal infection. Protein isolated from transgenic $A$. cepa generally causes inhibition for the growth of spore germination of $A$. niger. All these bioassays were applied to both transgenic $A$. cepa lines comparing to non-transgenic ones. The further studies will involve the impact on the onion's fleshy and scale leaves beside the onion seedlings.

\section{Declarations}

Funding: No funding received for this work

Conflict of Interest: All authors have nothing to disclose. 
Ethics approval: Not applicable

Consent to participate: All authors agree to the content of manuscript

Consent for publication: All authors agree for publication

Availability of data and material: All data materials are available in manuscript

Code availability: Not applicable

\section{Acknowledgment}

The authors would like to thank both the Botany and Microbiology Department- Faculty of Science Helwan University, and Agriculture Center for of Genetic Engineering and Biotechnology (ACGEB) Faculty of Agriculture - Ain Shams University.

\section{References}

1. Jurgiel-Malecka G, Gibczynska M, Nawrocka-Pezik M (2015) Comparison of Chemical Composition of Selected Cultivars of White, Yellow and Red Onions. Bulg J Agric Sci 21(4):736-741

2. Karthik SK, Satishkumar, Palanimuttu V (2016) Engineering Properties of Some Indian Onion Cultivars. Int J Agric Sci 8(29):1613-1617

3. Wani AH, Taskeen (2011) Management of black mold rot of onion. Mycopathol 9:43-49

4. Saranya R, Anadani VB, Akbari LF, Vanthana M (2017) Management of Black Mold of Onion [Aspergillus niger (Van Teigh)] by using Various Fungicides. Int J Curr Microbiol App Sci 6(3):16211627. doi:https://doi.org/10.20546/ijcmas.2017.603.187

5. Stec B (2006) Plant thionins - the structural perspective. Cell Mol Life Sci 63(12):1370-1385. DOI 10.1007/s00018-005-5574-5

6. Hoshikawa K, Ishihara G, Takahashi H, Nakamura I (2012) Enhanced resistance to gray mold (Botrytis cinerea) in transgenic potato plants expressing thionin genes isolated from Brassicaceae species. Plant Biotech 29:87-93

7. Stotz HU, Waller F, Wang K (2013) Innate immunity in plants: The role of antimicrobial peptides. Antimicrobial Peptides and Innate Immunity. Eds. S. Hiemstra, S.A.J. Zaat. Springer 29-51

8. Sadati Z, Tajik Ghanbari MA, Babaeizad V, Rahimian H (2014) Expression of thionin and PDF1.2 coding genes as antimicrobial peptides in interaction of rice against rice blast agent, Magnaporthe oryzea. Iran J Plant Path 50(4):147-149

9. Kurtoglu KY, Filiz E, Ozyigit II, Vatansever R (2015) Genome-Wide Analysis of Thionin Genes in Higher Plants, Plant and animal genome conference XXIII. San Diego, CA. https://pag.confex.com/pag/xxiii/webprogram/Paper14677.html

10. Odintsova TI, Slezina MP, Istomina EA (2018) Plant thionins: structure, biological functions and potential use in biotechnology. Vavilovskii Zhurnal Genetiki I Selektsii = Vavilov. Journal of Genetics 
Breeding 22(6):667-675. DOI 10.18699/VJ18.409

11. Asano T, Miwa A, Maeda K, Kimura M, Nishiuchi T (2013) The Secreted Antifungal Protein Thionin 2.4 in Arabidopsis thaliana Suppresses the Toxicity of a Fungal Fruit Body Lectin from Fusarium graminearum. PLoS Pathog 9(8):e1003581. doi:10.1371/journal.ppat.1003581

12. Kavipriya C, Yuvaraja A, Senthil K, Menaka C (2019) Genetic Transformation Methods for Crop Improvement: A Brief Review. Agric Rev 40(4):281-288

13. Raftery R, O'Brien FJ, Cryan SA (2013) Chitosan for Gene Delivery and Orthopedic Tissue Engineering Applications. Molecules 18:5611-5647

14. Li G, Wang J, Feng X, Liu Z, Jiang C, Yang J (2015) Preparation and Testing of Quaternized Chitosan Nanoparticles as Gene Delivery Vehicles. Appl Biochem Biotechnol 175:3244-3257

15. Shigemasa $Y$, Matsuura H, Sashiwa H, Saimoto H (1996) Evaluation of different absorbance ratios from infrared spectroscopy for analyzing the degree of deacetylation in chitin. Int J Biol Macromol 18:237-242

16. Periayah MH, Halim AS, Saad AZ (2016) Chitosan: A Promising Marine Polysaccharide for Biomedical Research. Phcog Rev 10:39-42

17. Seda Tiğli R, Karakeçili A, Gümüşderelioğlu M (2007) In vitro characterization of chitosan scaffolds: Influence of composition and deacetylation degree. J Mater Sci Mater Med 18:1665-1674

18. Zhang J, Xia W, Liu P, Cheng Q, Tahirou T, Gu W et al (2010) Chitosan modification and pharmaceutical/biomedical applications. Mar Drugs 8:1962-1987

19. Abdel-Razik AB, Hammad IA, Tawfik E (2017) Transformation of Thionin Genes Using Chitosan Nanoparticle into Potato Plant to Be Resistant to Fungal Infection. IOSR Journal of Biotechnology Biochemistry (IOSR-JBB) 3(3):1-13

20. Murashige T, Skoog K (1962) A revised medium for rapid growth and bioassays with tobacco tissue cultures. Physiol Plant 15:473-497

21. Lu Y, Chanroj S, Zulkifli L, Johnson MA, Uozumi N, Cheung A, Sze H (2011) Pollen tubes lacking a pair of K + transporters fail to target ovules in Arabidopsis. Plant Cell 23(1):81-93

22. Czechowska-Biskup R, Jarosińska D, Rokita B, Ulański P, Rosiak JM (2012) Determination of degree of deacetylation of chitosan - comparison of methods. Prog Chem Appl Chitin Deriv 17:5-20

23. Kiang T, Wen J, Lim HW, Leong KW (2004) The effect of the degree of chitosan deacetylation on the efficiency of gene transfection. Biomaterials Elsevier Ltd 25:5293-5301

24. Mansouri S, Cuie Y, Winnik F, Shi Q, Lavigne P, Benderdour M, Beaumont E (2006) Characterization of folate-chitosan-DNA nanoparticles for gene therapy. Biomaterials 27:2060-2065

25. Khan RS, Sjahril R, Nakamura I, Mii M (2008) Production of transgenic potato exhibiting enhanced resistance to fungal infections and herbicide applications. Plant Biotechnol Rep 2:13-20

26. Khan RS, Ntui VO, Chin DP, Nakamura I, Mii M (2011) Production of marker-free disease-resistant potato using isopentenyl transferase gene as a positive selection marker. Plant Cell Rep 30:587-597 
27. Bradford MM (1976) A Rapid and Sensitive Method for the Quantitation of Microgram Quantities of Protein Utilizing the Principle of Protein-Dye Binding. Anal Biochem 72:248-254

28. Liu Y, Luo J, Xu C, Ren F, Peng C, Wu G, Zhao J (2000) Purification, Characterization, and Molecular Cloning of the Gene of a Seed-Specific Antimicrobial Protein from Pokeweed. Plant Physiol 122:1015-1024

29. Plattner S, Gruber C, Stadlmann J, Widmann S, Gruber CW, Altmann F, Bohlmann H (2015) Isolation and Characterization of a Thionin Proprotein processing Enzyme from Barley. J Biol Chem 290(29):18056 - 18067

30. Almaghrabi B, Ali MA, Zahoor A, Shah KH, Bohlmann H (2019) Arabidopsis thionin-like genes are involved in resistance against the beet-cyst nematode (Heterodera schachtii). Plant Physiol Biochem 140:55-67

31. Hussien ET (2020) Production of transgenic Paulownia tomentosa (Thunb.) steud. using chitosan nanoparticles to express antimicrobial genes resistant to bacterial infection. Mol Biol Res Commun $9(2): 55-62$

32. Bivas-Benita M, Romeijn S, Junginger HE, Borchard G (2004) PLGA-PEl nanoparticles for gene delivery to pulmonary epithelium. Eur J Pharm Biopharm 58:1-6

33. Hallaj-Nezhadietel S, Valizadeha H, Dastmalchia S, Baradaranc B, Jalalia MB, Dobakhtid F, Lotfipoure F (2011) Preparation of Chitosan-Plasmid DNA Nanoparticles Encoding interleukin-12 and their Expression in CT-26 Colon Carcinoma Cells. J Pharm Pharmaceut Sci 14(2):181-195

34. Cammue BPA, De Bolle MFC, Terras FRG, Proost P, Van Damme J, Rees SB, Vanderleyden J, Broekaert WF (1992) Isolation and characterization of a novel class of plant antimicrobial peptides from Mirabilis jalapa L. seeds. J Biol Chem 267:2228-2233

35. Epple P, Apel K, Bohlmann H (1997) Overexpression of an endogenous thionin enhances resistance of Arabidopsis against Fusarium oxysporum. Plant Cell 9(4):509-520

\section{Figures}




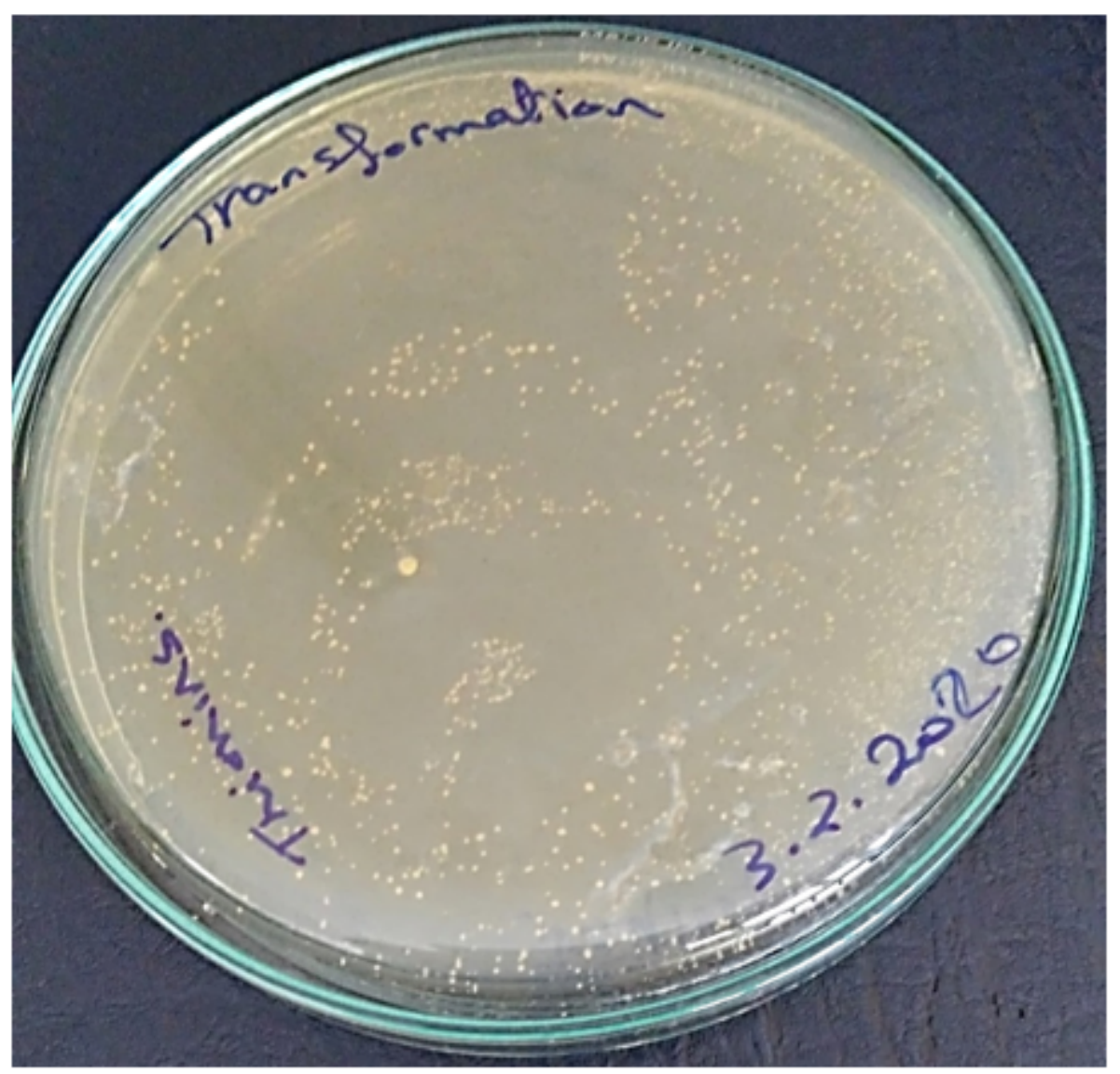

Figure 1

Transformation of Thio-60 and growth of recombinant 10-beta (E. coli) on LB supplemented with $100 \mu \mathrm{g} / \mathrm{L}$ ampicillin. 


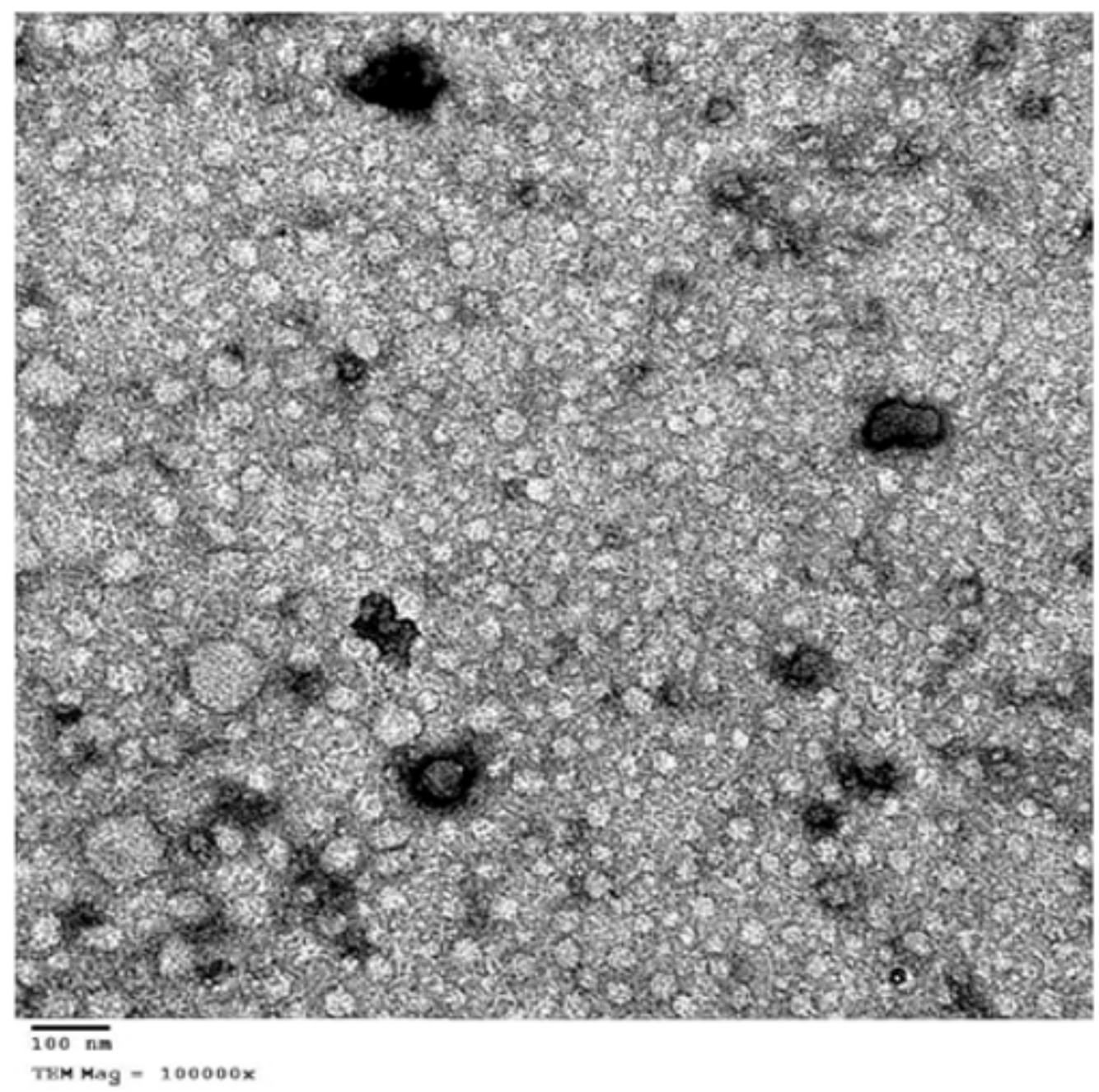

Figure 2

TEM of chitosan nanoparticle unit with recombinant pMini-T carrying thio-60 gene. JOEL JEM-1010 Electrom Microscope. Image scales: 100nm.

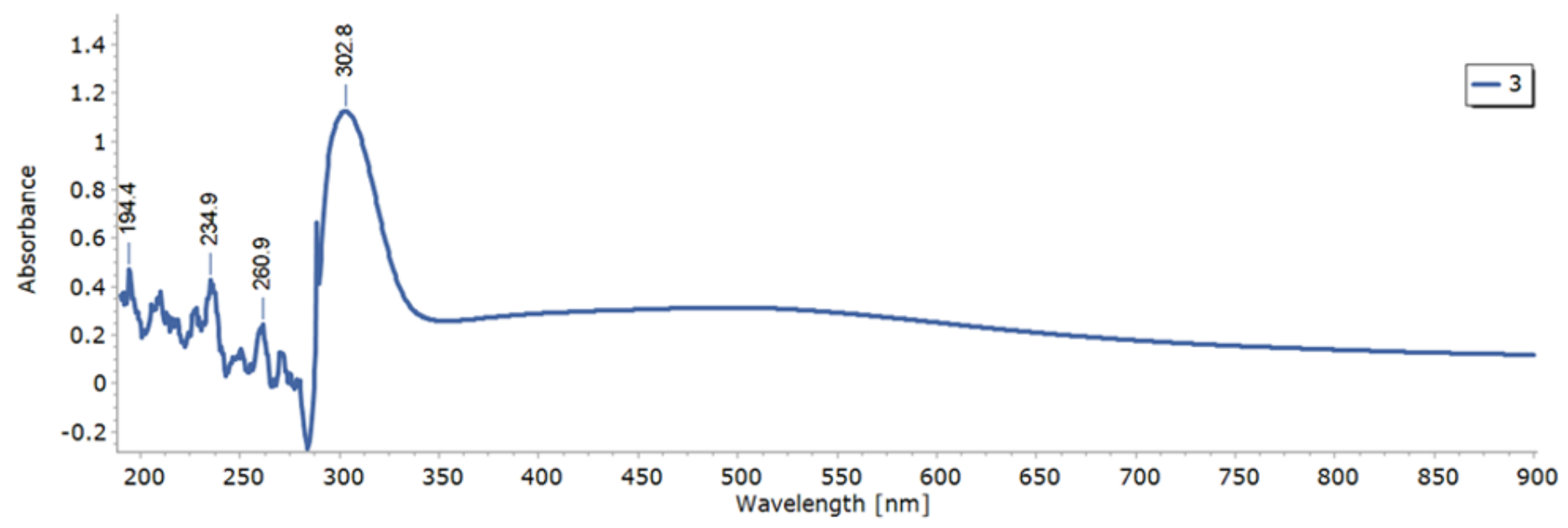

Figure 3 
UV-visible spectroscopy of chitosan nanoparticles. Ultraviolet Spectrum JASCO. (Range: 190-900nm).

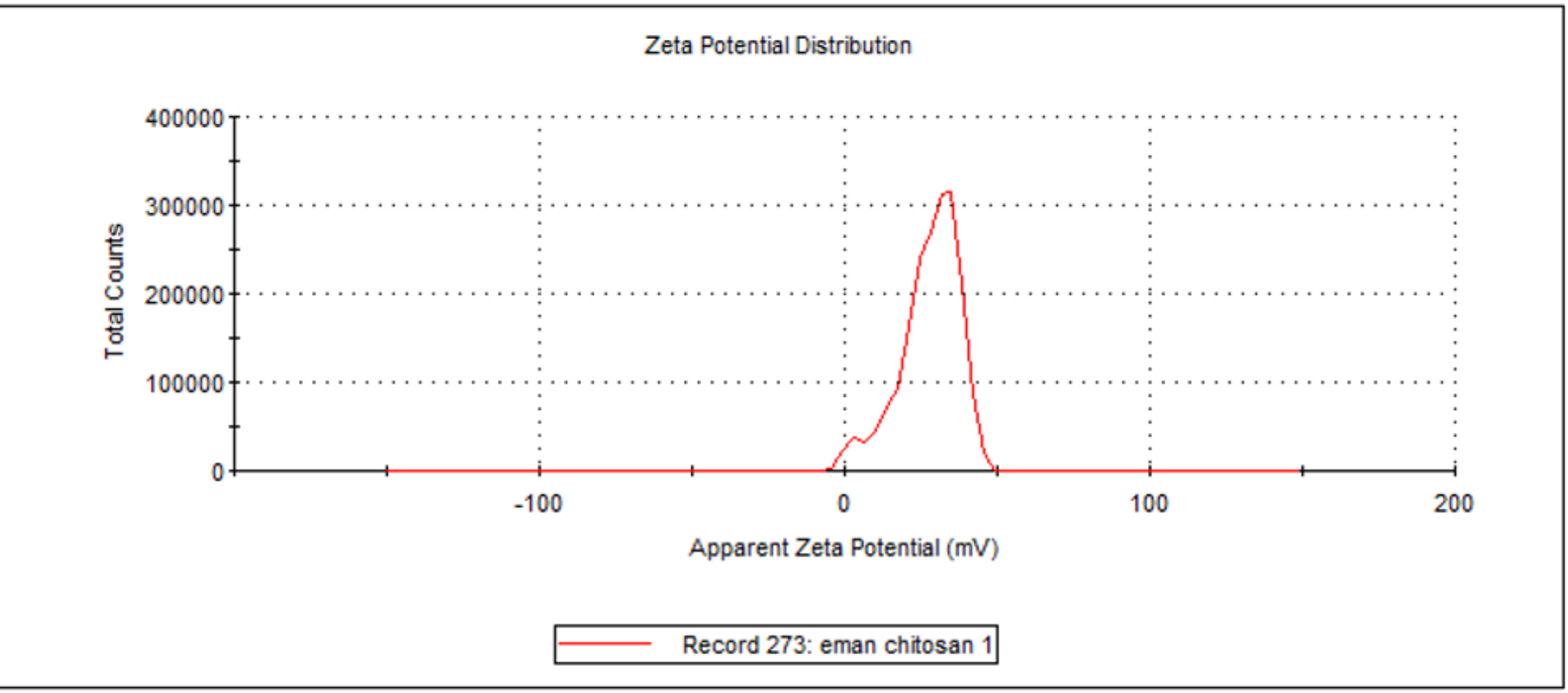

Figure 4

Zeta potential distribution of chitosan nanoparticles. Zetasizer Ver. 7.12, Malvern Instruments Ltd.

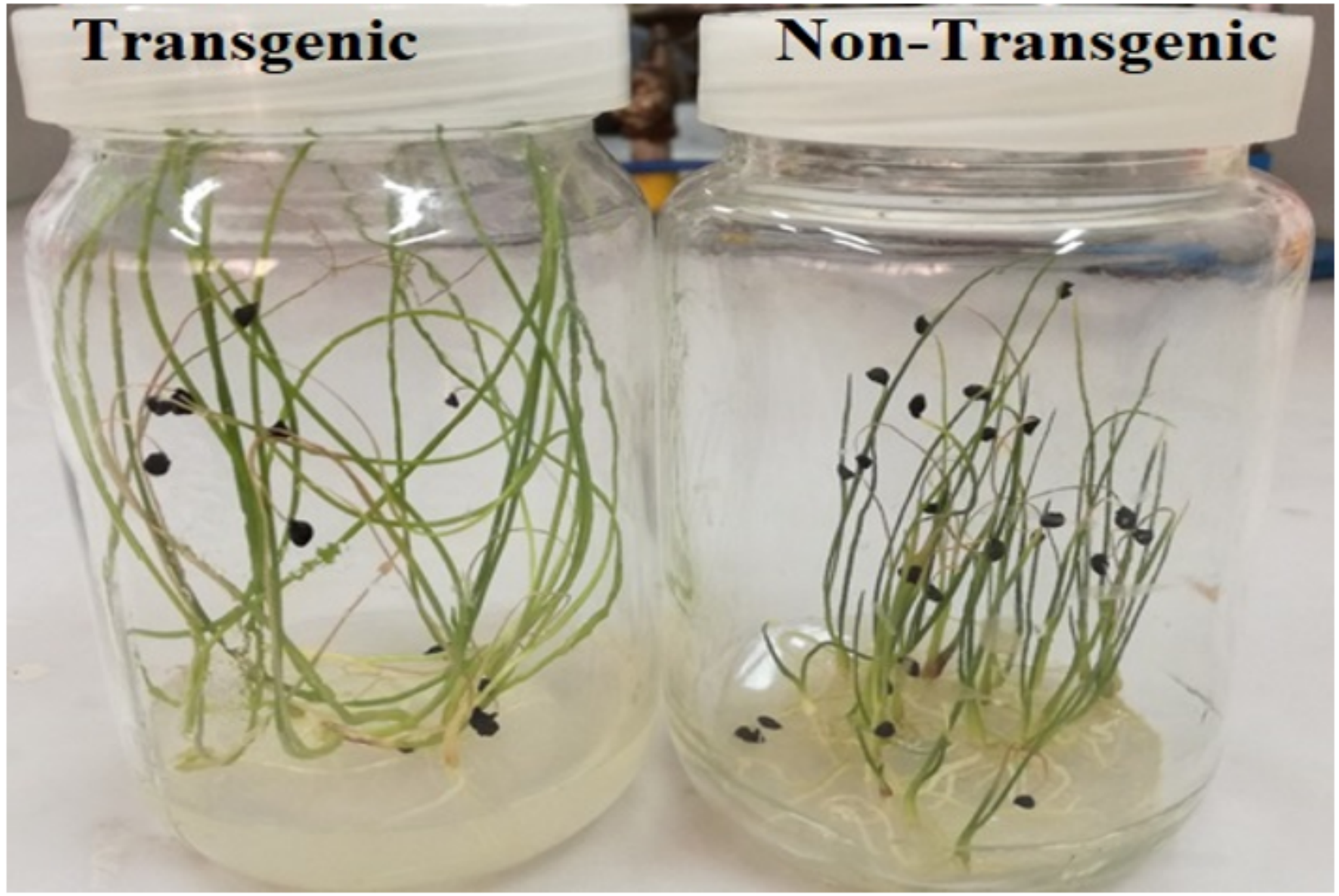




\section{Figure 5}

Non-Transgenic and transgenic Allium cepa with thio-60 on MS supplemented with hormones $(2 \mathrm{mg} / \mathrm{L} \mathrm{BA}$ and $1 \mathrm{mg} / \mathrm{l} \mathrm{kin)}$ and $100 \mu \mathrm{g} / \mathrm{L}$ ampicillin.

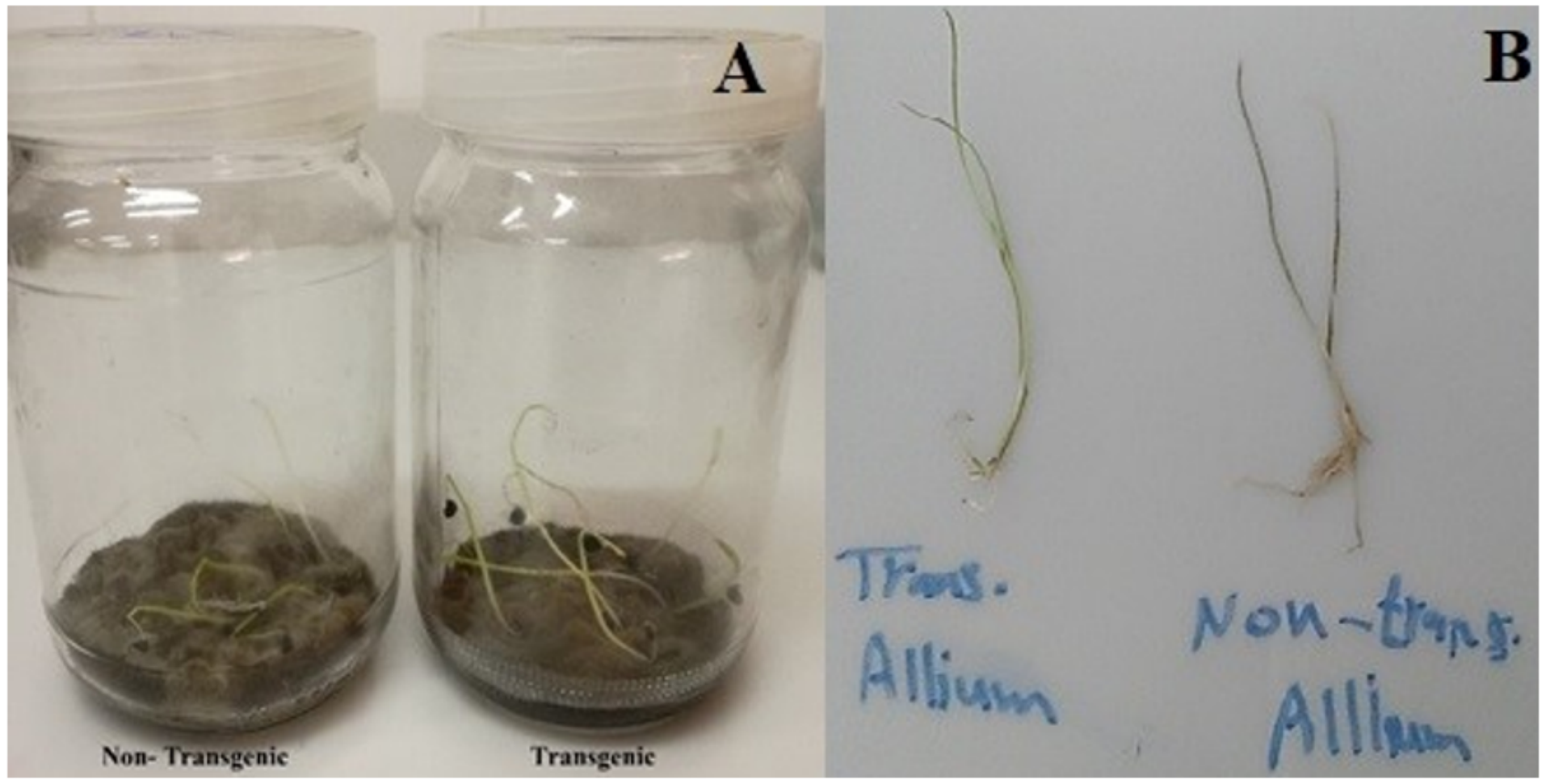

\section{Figure 6}

Transgenic and non-transgenic Allium cepa lines infected with A. niger

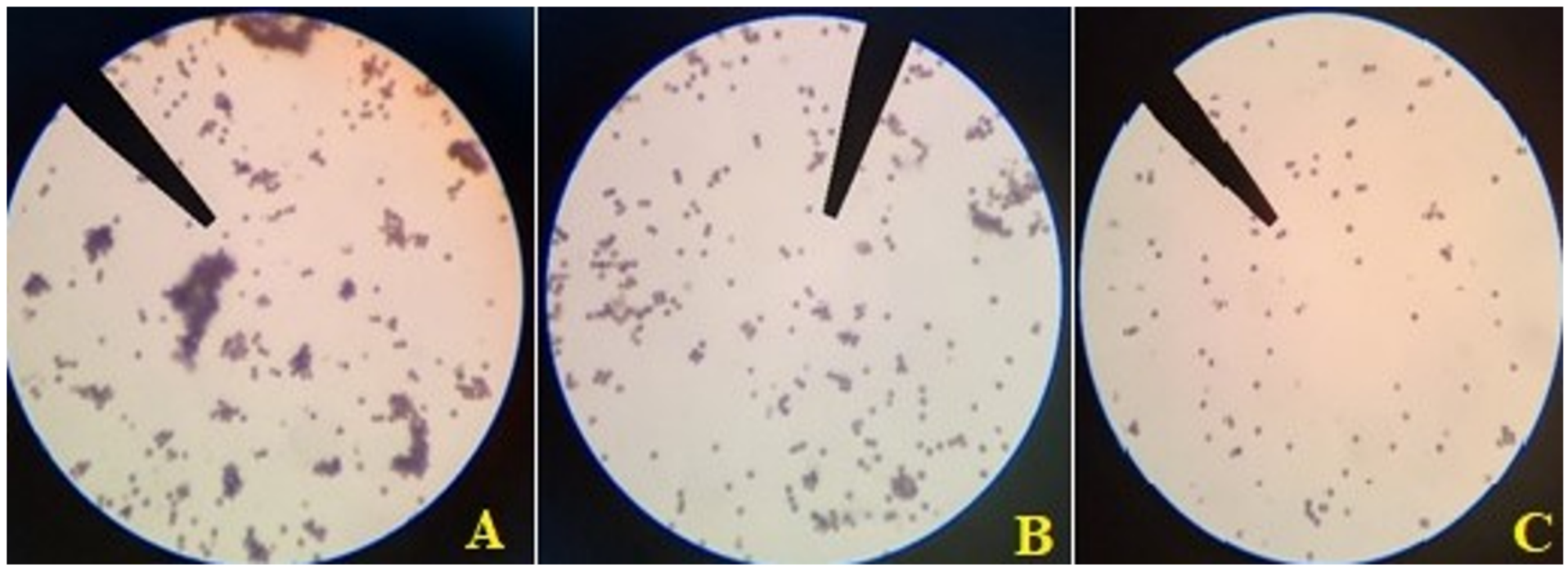

Figure 7

Effect of inhibitory thionin protein isolated from transgenic A. cepa on spore germination of A. niger. (a) spores treated with $\mathrm{H} 2 \mathrm{O}$ as negative control; (b) spores treated with non-transgenic plant protein as 
positive control; (c) spores treated with transgenic thio-60 protein plant protein. 